\title{
A Study of the Determinants of Effective Relationship Marketing Practices on Organisational Growth in the Medium Sized Hotel Industry of Pakistan
}

\author{
Umair Zahid $P h D$ \\ University of the West of Scotland, UK \\ E-mail: umair_zahid07@yahoo.com \\ Rizwan Tariq $P h D$ \\ University of the West of Scotland, UK \\ Nosheen Maqbool PhD \\ University of the West of Scotland, UK \\ Mudasir Hussain $P h D$ \\ University of the West of Scotland, UK \\ Junaid Khan $P h D$ \\ University of the West of Scotland, UK \\ E-mail: Junaidkhan00@hotmail.com \\ Patrice Seuwou $P h D$ \\ University of Northampton, UK
}

\begin{abstract}
The current study evaluates the determinants of effective relationship marketing (RM) practices on the organisational growth in the medium sized hotel industry of Pakistan. To attain the information about the topic, Hotel Days Inn has been selected. The current study has used the quantitative research design for obtaining the desired information. The developed survey questionnaire was distributed among the 273 customers of the Hotel Days Inn. In the study, a series of non-parametric tests like Chi-square, Descriptive analysis, and Spearman Rank Correlation was performed for quantitative findings. With the help of such statistical findings, it was observed that most of the research variables were taken into consideration due to their positive relationship with the organisational growth. That is, the Spearman correlation value for the customer satisfaction and organisational growth was calculated as 0.968 explaining the strong relation between the research variables. The developed research also displays different determinants for RM practices that has a direct influence on the organisational growth of the medium sized hotel industry of Pakistan. The acquired results of research also help the researcher in developing recommendations. These recommendations were based on the targeting practices of the hotels for attracting the customers and hiring of the trained and skilled staff that can positively influence the organisational growth and improve the RM practices.
\end{abstract}

Keywords: Relationship Marketing (RM), Organisational Growth, Marketing Practices, Medium Sized Hotel Industry,Pakistan, Hotel Industry, Determinants of Relationship Marketing Practices.

\section{Introduction}

The modern business era requires the organisations to establish a healthy and strong relationships with their target customers so that they can develop strategies to retain the customers and can easily increase the level of profits. This was discussed by Ptezer, Steyn, and Moster (2009) with specific reference of the service industry where the customers always expect more.

\section{I.I Background of Study}

A study conducted by Opuni, Opoku, and Afful (20I4) states the fact that the developed relation between the customers and their respected organisations are basic forces that derive the success and growth in the service industry. Such developed relation between the business and its customers also highlight the concept of relationship marketing. Christou (20I0) describes the concept of relationship marketing (RM) as the process through which the relations between organisations and its customers are maintained and improved for increasing the corporate goodwill and financial performance. 
In respect of the hotel industry, the practise of RM work as the powerful tool for the business for developing their competitive advantage with other businesses working in the same industry. The relationship developed among the businesses and the customers is developed by the application of strategic extension of the 4 Ps of the marking termed as 7 Ps of marketing (Jones, 2010). Moreover, Williams (2006) has identified three main directions of strategic development in the RM practices. First and foremost, the business must offer basic services to the customers for developing a starting point for the relations. Secondly, the business must adapt change in the service delivery to the target customers with the help of numerous discounts and loyalty benefits. Lastly, the businesses must invest internally to train and motivate the employees so that they can deliver better customer services (Dominici and Guzzo, 2010).

\section{I.2 Industry and Company Background}

In Pakistan, the hotel industry is considered as the respectable and important industry of the country as it has durable stakes in the public and the private sector of the country. Siddiqui (2016) has mentioned in their news article, published in the Express Tribune, that the hotel industry of Pakistan had acquired great attention from the international community after the introduction of the China-Pakistan Economic Corridor (CPEC). This interest by the international community members had increased the need of hotel industry development. In this respect, the $80 \%$ of the development in the hotel industry is performed in past couple of years.

The hotel industry of Pakistan also consists of medium sized hotels. These medium sized hotels provide long-term stay and full accommodation services in comparison of the small sized hotels (Dar, Ahmed and Raziq, 2017). One of the selected medium sized hotels for the research is Hotel Days Inn. The selected hotel is located in the city of Karachi, Pakistan; that provide the services for fulfilling the discriminating needs of the individual travellers who look for privacy, personalised services and franchise hotel elegance. The hotel is situated between the finest shopping malls that are away from city's main airport at the I0-minute drive. The level of services that are provided by the Days Inn Hotel are based on the high-quality services from the management respondents of the hotel (Hotel Days inn, 2019).

Palm tier (2008) and Gambeson (20II) had discussed that the relationship marketing (RM) practices are the important practices for the hotel industry as it helps the management of hotel in attracting and retaining the customers for increasing the revenue of the industry. Gummesson (20II) also acclaims the fact that the effective RM practices in the hotel industry and help the hotel management in making continuous improvement in the business strategies that support the customer feedback. In this manner, the hotel management become able to retain and attract customers in an effective manner (Wang, 2012). Even though the RM practices has great importance in the hotel industry, but the hotel industry of Pakistan lacks the evidence about the effective use of RM practices for customers' satisfaction; retention; and increased loyalty. Therefore, it is considered important for eh Hotel industry of Pakistan to find the need of using RM practices in the industry (Hashim et al. 2016).

The study conducted by Hashim et al., (2016) has identified three main weaknesses of the Pakistan's hotel industry that lacks the evidence. These three factors can be described as the lack in the infrastructure, poor management services and absences of government legislation. Therefore, there is a need to conduct a research that can easily help the hotel industry of Pakistan in understanding the importance of RM practices for acquiring the growth opportunities. Moreover, the problem of the study is also related with selected Hotel Days Inn. Even though the hotel is popular but there are no evidences of using the RM practices in the customer satisfaction (Grissemann and Stokburger-Sauer, 20I2); customer retention (Mohammed, Rashid and Tahir, 2017); business image (Mok, Sparks and Kadampully, 2013); food quality (Dabholker, 20I5); and service quality (Dabholker, 20I5).

In order to find solution, the current study has critically reviewed the past studies that describe the determinants of the RM practices and had developed a conceptual framework that identifies its impact on the organisational growth of the Hotel Days Inn.

In prior studies, there are certain research gaps in relation of determining the impact of the relationship marketing (RM) practices in the hotel industry of the Pakistan and none of the study has studied the RM practice of either collective or an individual hotel of the hotel industry. Therefore, the current study is developed for making its contribution in the research for identifying the major determinants of the RM practices within the hotel industry of Pakistan. Moreover, the current study has the main aim for critically evaluating the influence of the RM practices on the organisational growth operating in the medium sized hotel industry and recommend the effective determinants.

\section{Literature Review}

\section{I Conceptualisation of Relationship Marketing}

Relationship marketing (RM) has been defined as the process of developing, maintaining, and terminating relational exchanges for increasing the overall business performance (Palmatier, 2008). Moreover, Gummesson (20II) has countered the mentioned definition of RM and states that, "RM practices are the facets of the customer relationship marketing that has its focus on the long-term customer engagement rather attaining the short-term goals. " Zhang et al. (2016) has conducted their research on the 
RM practices and had described the process as the type of interaction made in the network of customers and follows the guidelines of the customer relationship management (CRM).

Oly and Kook (2005); and Kandampully et al. (2015) had described the relationship marketing as the process of customer satisfaction that must be attained by the organisations like Hotel Day Inn of Karachi. To understand the concept of the RM practices in the Hotel industry of Pakistan; Sheth (2017) has explained two main objectives of performing the effective RM practices. First objective is based on the effective management of the customer relations; whereas, the second objective is based revitalising the concept of RM performed with the consumers. It was also explained by Gummerus, von-Koskull and Kowakowski (2017) that the RM practices of the hotel industry can be purposely develop by the rise in the service industry that focuses its operations on the consumer service outcomes.

\subsection{Marketing Mix of Relationship Marketing}

When developing the marketing mix for the service industry like the hotel industry, Chaffey and Smith (2017) has explained that the marketing mix of the services industries is derived from the 7Ps of marketing. These 7Ps include product, price, place, promotion, people, packaging, and positioning. Kotler, Kartajaya and Setiawan (2016) has also explained the fact that the RM practices had been evolved from the marketing mix practices that initially develops its focus on the transactional characteristics of the hotel industry that are now shifted with the relationship building practices. It has been critiqued by the Armelini and Villanueva (20II) that the marketing mix is the effective tool that promote the concept of marketing products and services in the respective markets. Yet, the marketers of the service industry cannot rely on the marketing mix practices for supporting the RM practices.

The concept of 7Ps of marketing has been changed to support the functionality of the RM practices in the service industry. These changed aspects are interaction, emotional content, customer life time values and customisation (Zhang et al. 2016). The interaction aspect is related with the people of the $7 \mathrm{P}$. The interaction practices involve the handling practices of the management with the clients and the customers of the hotel industry (Gronroos, 2017). The emotional content aspect of the $\mathrm{RM}$ is in relation of the promotion, product and positioning of the services of the hotel industry. That is, the management practices for promoting and positioning the services of the hotel industry are developed with the emotional content (Sahin, Zehir and Kitapci 20I I). The customer lifetime values is related to the price of the services that are offered to the market. That is, the price develops the economic link of the eservices delivered with effective RM practices (Kehreh et al. 20I4). The last aspect of the RM practices of customisation is linked with the physical existence of the services that are provided to the customers of the hotel industry (Coelho and Henseler 2012).

\subsection{Determinants of Effective Relationship Marketing in Hotel Industry}

As the customers are having increased level of expectations in the service industry of the medium sized hotels, the management of the hotel services in the region required the continuous development and improvement in the services delivery to the target customers (Halinen, 2012). It is also observed from Azzan and Khasawneh (2017) that the customers of the service industry are getting conscious for the quality of the services that are been delivered to them. Moreover, the determinants such as commitment, trust, handling of conflicts, quality of food and services provided to the customers plays an important role in determining the level of RM practices performed by the hotels like Hotel Days Inn in the hotel industry.

Moreover, the determinants that are considered important in the hotel industry with respect to effective performance of the relationship marketing practices are described as customer retention, customer satisfaction, price level, food quality, service quality, and business image. Customer retention practices are described by Christopher, Payne and Ballantyne (20I3) as the practices that are implemented by the organisations for reducing the level of displeasure developed by the customers while using the services. It is also discussed by Mohammed, Rashi and Tahir (2017) customer retention helps the organisations in increasing the level of profitability with effective growth to the business. $\backslash$

Segoro (2013); and Ramaseshan, Wirtz and Georgi (2017) has described the concept of the customer satisfaction as the point at which the loyalty acquisition from the customers is explained by the level of experience displayed by the clients after using the products and services. For acquitting the desired level of customer satisfactions, the hotel industry must provide a superior level of customer services as the satisfied customers do lead the business towards success. It is also described by Nicolau and Santa-Maria (2013); and Bowie et al (2016) that the prices and its effective management plays an important role in the success of the hotel industry as price level of the hotel describes the level of quality of the service and food that is offered to the customers.

It has been explained by the Davis et al. (2018) that the consumers had become responsible for their well-being and living the healthy life, therefore, they had increased the level of intolerance for the food and services that are of lower quality. The service quality has been an important factor for the service industry sector as they had been the most challenging factor (Raza et al. 2012). Further, Bowie et al. (2016) has explained the fact that the services quality is the factor that can help the hotels in increasing the number of customers through increase satisfaction level. Though, the concept of service quality is based 
on the perspectives of the consumers. So, the increased level of service quality can result in the increase in the chances of changed perspectives of the clients about the delivered services (Mok, Sparks, and Kadampy, 2013).

\subsection{Conceptual Framework}

In the current section, the current researcher has produced a conceptual framework that is bee emerged from the determinants of the relationship marketing discussed in the previous sections of the literature. These determinants were customer retention, customer satisfaction, price, food quality, and service quality and brand image. All of these determinants are ben analysed quantitatively. The Following figure 2.12 describes the association among the developed determinants of the relationship marketing with the organisational growth in the hotel industry. The statistical techniques used on the quantitative data are explained in the data analysis section of the article.

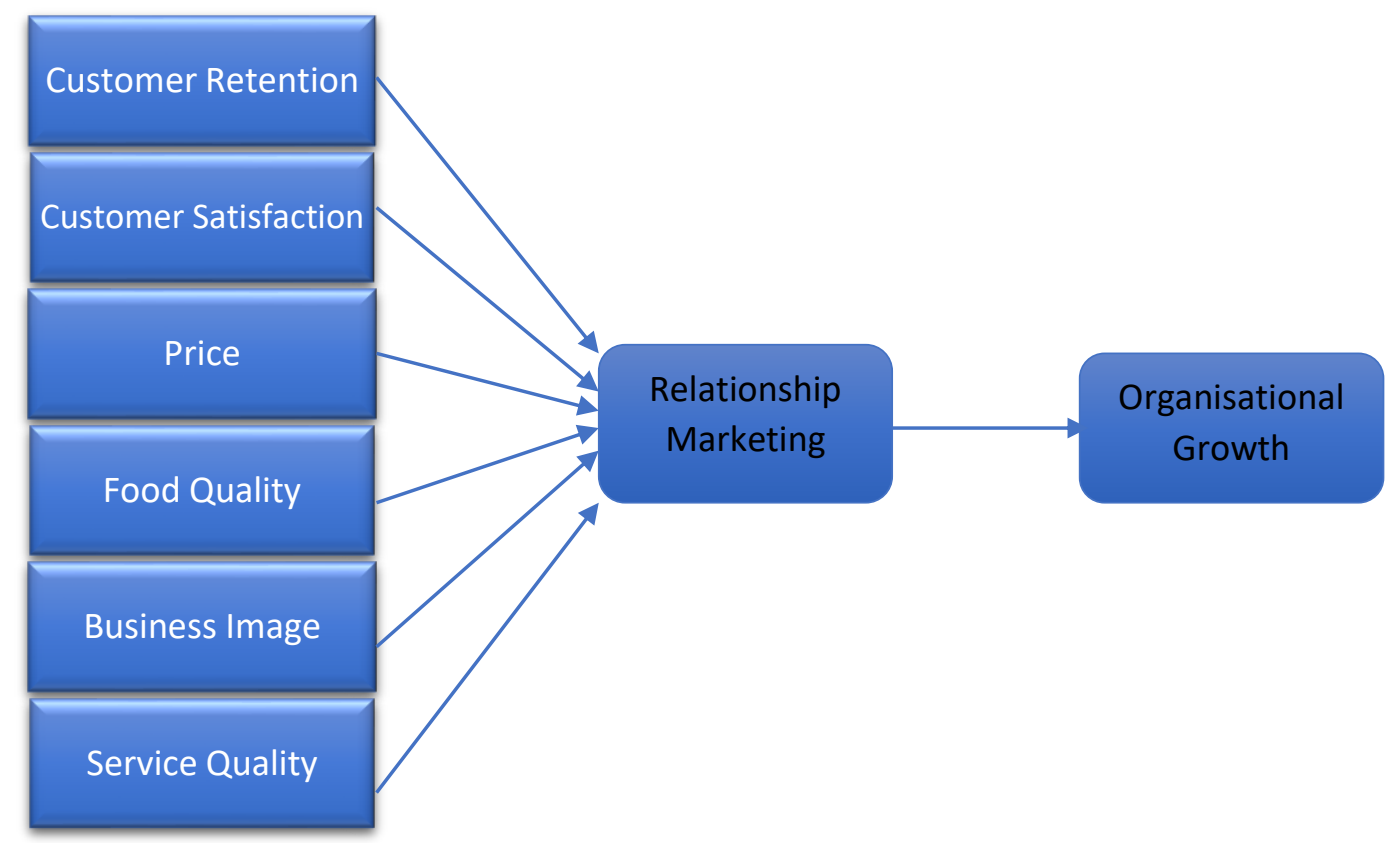

Figure I. Conceptual Framework

\subsection{Research Hypotheses}

Ha: Customer retention of Pakistan's hotel industry affects the organisational growth significantly.

$\mathrm{Hb}$ : Customer satisfaction of Pakistan's hotel industry affects the organisational growth significantly.

Hc: Price of Pakistan's hotel industry affects the organisational growth significantly.

Hd: Food quality of Pakistan's hotel industry affects the organisational growth significantly.

He: Business image of Pakistan's hotel industry affects the organisational growth significantly.

Hf: Service quality of Pakistan's hotel industry affects the organisational growth significantly.

\section{Research Methodology}

In the current study, the research methodology is based on the quantitative approach. This approach was used to analyse the numerical data so the developed research aims can be attained (Yin, 2003). The use of quantitative research approach helped the researcher in determining the use of positivist research philosophy that supports the use of quantitative approach of research. The positivist research philosophy permitted the researcher to make opinions of real-world and make interpretation from them in a neutral manner to gather realistic evidence (Silverman 2016). With the implementation of positivism philosophy, the researcher retained minimal communication with the members of the study for attaining effective and excellent data that do not include any sort of biasness (Gilson and Levinson, 2012). With the quantitative approach and positivist research philosophy, the current research also adopts the deductive technique of research so the developed research objectives and hypotheses can be tested. In this manner, the research can easily reach towards the results of the research (Teddie and Tashakkon, 2009). 


\section{I Data Collection}

As the current research article follows the quantitative research approach with the positivist research philosophy, the data collection for the research is based on the primary data collection technique of developing and distributing the questionnaire based on the Likert Scale measure. This Likert Scale Measure is based on five points for answering the question. These five points are "Strongly Disagree, Disagree, Neutral, Agree, and strongly Agree". This questionnaire was developed and was distributed among the selected sample for collecting the large data in the small period of time.

\subsection{Data Analysis}

For analysing the collected data, the current research uses the statistical data analysis techniques based on Cronbach's Alpha; Spearman's Rank Correlation; and Chi Square test. These tests were employed through the use of Statistical Package for Social Science (SPSS). The software enables the researcher in testing the data from the exported excel file of the responses provide by the respondents through filling the distributed questionnaire.

\subsection{Sample Size and Technique}

The sampling method that was used for the research was based on the convenience sampling techniques of non-probability sampling methods. This convenience sampling technique can help the researchers in collecting the responses from the customers on the willingness and availability of the participants (Creswell et al. 2003). It was estimated by Ali (2010) that around 40,000 of the customers have been associated with medium sized hotels services in Pakistan. This number of population helped the researcher to determine the sample size. The current sample size for the research is the total of 38I respondents. Though, there is a possibility that some of the respondents might not completely fill the questionnaire; so, these questionnaire responses will be avoided. So, a total of 273 completed questionnaires were included in the research.

\section{Results and Discussion}

For every research, results and discussion section is very important as the quantitative collected data had to be analysed and the results had to be explained in the manner that led towards the objective attainment.

\section{I Cronbach's Alpha}

For measuring the responses, the research dependent variable was organisational growth. The independent variable or research was relationship marketing (RM) practices. These RM practices were described as customer retention, customer satisfaction, price, food quality, service quality, and business image. For determining the internal consistency of the measuring instrument; reliability testing was executed by means Cronbach's alpha:

\section{Table I. Reliability Statistics}

\begin{tabular}{|c|c|}
\hline \multicolumn{2}{|c|}{ Reliability Statistics } \\
\hline Cronbach's Alpha & $\mathrm{N}$ of Items \\
\hline .981 & 18 \\
\hline
\end{tabular}

For supporting the consistency of the scale, the value of Cronbach Alpha must be more than the value of 0.70. From the determined result, the value of Cronbach's Alpha is $0.98 \mathrm{I}$ which is greater than 0.7 . This means that the scale used in the research is internally consistent.

\subsection{Spearman Rank Correlation}

A researcher conducts the correlation analysis when he or she wishes to identify the strength of the relationship between the dependent and independent variables of research (Astivia and Zumbo, 2017). Spearman correlation is performed for the analysing the relation between the variables with the help of monotonic function unlike the Pearson correlation (Chok, 20I0) 
Table 2. Spearman Rank Correlation Test

Correlations

\begin{tabular}{|c|c|c|c|c|c|c|c|c|c|}
\hline & & & $\begin{array}{l}\text { Customer } \\
\text { retention }\end{array}$ & $\begin{array}{l}\text { Customer } \\
\text { satisfaction }\end{array}$ & Price & Food quality & Senvice quality & $\begin{array}{c}\text { Business } \\
\text { image }\end{array}$ & $\begin{array}{l}\text { Organisationa } \\
\text { I growth }\end{array}$ \\
\hline \multirow[t]{21}{*}{ Spearman's rho } & \multirow[t]{3}{*}{ Customer retention } & Correlation Coefficient & 1.000 & $.961^{\prime \prime}$ & $.940^{\prime \prime}$ & $.942^{\prime \prime}$ & $.937^{\prime \prime}$ & $.899^{\prime \prime}$ & $.915^{11}$ \\
\hline & & Sig. (2-tailed) & & .000 & .000 & .000 & .000 & .000 & .000 \\
\hline & & N & 273 & 273 & 273 & 273 & 273 & 273 & 273 \\
\hline & \multirow[t]{3}{*}{ Customer satisfaction } & Correlation Coefficient & $.961^{\prime \prime}$ & 1.000 & $.973^{\text {"I }}$ & $.975^{\prime \prime}$ & $.989^{\prime \prime}$ & $.951^{\prime \prime}$ & $.968^{\prime \prime \prime}$ \\
\hline & & Sig. (2-tailed) & .000 & & .000 & .000 & .000 & .000 & .000 \\
\hline & & $\mathrm{N}$ & 273 & 273 & 273 & 273 & 273 & 273 & 273 \\
\hline & \multirow[t]{3}{*}{ Price } & Correlation Coefficient & $940^{\prime \prime}$ & $.973^{\prime \prime}$ & 1.000 & $.988^{\prime \prime}$ & $.965^{\prime \prime}$ & $.890^{\prime \prime}$ & $.911^{\prime \prime}$ \\
\hline & & Sig. (2-tailed) & .000 & .000 & & .000 & .000 & .000 & .000 \\
\hline & & N & 273 & 273 & 273 & 273 & 273 & 273 & 273 \\
\hline & \multirow[t]{3}{*}{ Food quality } & Correlation Coefficient & $.942^{11}$ & $.975^{\prime \prime}$ & $.988^{\prime \prime \prime}$ & 1.000 & $.967^{\prime \prime}$ & $.880^{\prime \prime}$ & $.901^{11}$ \\
\hline & & Sig. (2-tailed) & .000 & .000 & .000 & & .000 & .000 & .000 \\
\hline & & N & 273 & 273 & 273 & 273 & 273 & 273 & 273 \\
\hline & \multirow[t]{3}{*}{ Senvice quality } & Correlation Coefficient & $.937^{11}$ & $.989^{\prime \prime}$ & $.965^{m 1}$ & $.967^{\prime \prime \prime}$ & 1.000 & $.942^{\prime \prime}$ & $.956^{11}$ \\
\hline & & Sig. (2-tailed) & .000 & .000 & .000 & .000 & & .000 & .000 \\
\hline & & N & 273 & 273 & 273 & 273 & 273 & 273 & 273 \\
\hline & \multirow[t]{3}{*}{ Business image } & Correlation Coefficient & $.899^{\prime \prime}$ & $.951^{\prime \prime}$ & $.890^{\prime \prime}$ & $.880^{\prime \prime}$ & $.942^{\prime \prime}$ & 1.000 & $.980^{\prime \prime \prime}$ \\
\hline & & Sig. (2-tailed) & .000 & .000 & .000 & .000 & .000 & . & .000 \\
\hline & & N & 273 & 273 & 273 & 273 & 273 & 273 & 273 \\
\hline & \multirow[t]{3}{*}{ Organisational growth } & Correlation Coefficient & $.915^{\prime \prime}$ & $.968^{\prime \prime}$ & $.911^{\prime \prime}$ & $.901 "$ & $.956^{\prime \prime}$ & $.980^{\prime \prime}$ & 1.000 \\
\hline & & Sig. (2-tailed) & .000 & .000 & .000 & .000 & .000 & .000 & \\
\hline & & $\mathrm{N}$ & 273 & 273 & 273 & 273 & 273 & 273 & 273 \\
\hline
\end{tabular}

**. Correlation is significant at the 0.01 level (2-tailed).

Table 2 describes the level of correlation between the research variables. It is observed from the table that the spearman correlation between customer retention and organisation growth is 0.9I5 that signifies the strong relation among variables. The Spearman coefficient of customer satisfaction and organisation growth is valued at 0.986 that also displays a strong relation. Price and organisational growth has the Spearman correlation coefficient value of 0.9I I depicting a strong relation. The relation bond between food quality and organisational growth is also strong with a value of 0.90I. Moreover, there is a strong relation between service quality and organisation growth with the value of 0980 .

\subsection{Chi-Square Test}

The Chi-square test is used for understanding and examining the relationship between the research variables.

Table 3. Chi-Square Tests (Customer Retention and Organisational Growth)

\begin{tabular}{lrrr}
\hline & Value & $\mathrm{df}$ & Asymp. Sig. (2-sided) \\
\hline Pearson Chi-Square & $21.896^{\mathrm{a}}$ & & \\
\cline { 3 - 4 } & & 4 & .000 \\
\hline Likelihood Ratio & 2I.69I & 4 & .000 \\
\hline $\begin{array}{l}\text { Linear-by-Linear } \\
\text { Association }\end{array}$ & $\mathrm{I} 4.846$ & $\mathrm{I}$ & .000 \\
\hline N of Valid Cases & & & \\
\hline a. 2 cells $(5.5 \%)$ have expected count less than 5. The minimum expected count is 3.00.
\end{tabular}

Table 4. Symmetric Measures (Customer Retention and Organisational Growth)

\begin{tabular}{clrr}
\hline & & Value & Approx. Sig. \\
\hline Nominal by Nominal & Phi & .283 & .000 \\
\hline & Cramer's & .200 & .000 \\
& V & & \\
\hline N of Valid Cases & & 273 & \\
\hline
\end{tabular}


The first chi-square table (3) is determined between the organisational growth and customer retention. The Pearson Chi-square value is 21.896 with the sig value of 0.000 . Therefore, the relation between the variables is significant. Whereas the values of Phi in the symmetric measures (Table 4) is below the threshold of 0.3 i.e. 0.283; so, the relation is not that strong.

Table 5. Chi-Square Tests (Customer Satisfaction and Organisational Growth)

\begin{tabular}{lccr}
\hline & Value & df & Asymp. Sig. (2-sided) \\
\hline Pearson Chi-Square & $200.519^{a}$ & 4 & .000 \\
\hline Likelihood Ratio & 232.796 & 4 & .000 \\
\hline $\begin{array}{l}\text { Linear-by-Linear } \\
\text { Association }\end{array}$ & 156.325 & $\mathrm{I}$ & .000 \\
\hline N of Valid Cases & & & \\
\hline
\end{tabular}

a. I cells (I I.I\%) have expected count less than 5. The minimum expected count is 2.92 .

Table 6. Symmetric Measures (Customer Satisfaction and Organisational Growth)

\begin{tabular}{clcr}
\hline & & Value & Approx. Sig. \\
\hline Nominal by Nominal & Phi & .857 & .000 \\
\hline & Cramer's & .606 & .000 \\
& V & & \\
\hline N of Valid Cases & & 273 & \\
\hline
\end{tabular}

The second chi-square table (Table 5) is determined between the organisational growth and customer satisfaction. The Pearson Chi-square value is 200.519 with the sig value of 0.000 . Therefore, the relation between the variables is significant. Whereas the values of Phi in the symmetric measures (Table 6) is 0.857 , so the relation is very strong.

Table 7. Chi-Square Tests (Price and Organisational Growth)

\begin{tabular}{lccr}
\hline & Value & df & \multicolumn{2}{c}{ Asymp. Sig. (2-sided) } \\
\hline Pearson Chi-Square & $227.299^{a}$ & 4 & .000 \\
\hline Likelihood Ratio & 242.837 & 4 & .000 \\
\hline $\begin{array}{l}\text { Linear-by-Linear } \\
\text { Association }\end{array}$ & 164.608 & $\mathrm{I}$ & .000 \\
\hline N of Valid Cases & & & \\
\hline
\end{tabular}

a. 2 cells $(5.5 \%)$ have expected count less than 5 . The minimum expected count is 2.42 .

Table 8. Symmetric Measures (Price and Organisational Growth)

\begin{tabular}{clcc}
\hline & & Value & Approx. Sig. \\
\hline Nominal by Nominal & Phi & .912 & .000 \\
\hline & Cramer's & .645 & .000 \\
\hline N of Valid Cases & & & \\
\hline
\end{tabular}

The third chi-square table (Table 7) is determined between the price and organisational growth. The Pearson Chisquare value is 227.299 with the sig value of 0.000 . Therefore, the relation between the variables is significant. Whereas the values of Phi in the symmetric measures (Table 8 ) is 0.912 , so the relation is very strong. 
Table 9. Chi-Square Tests (Food Quality and Organisational Growth)

\begin{tabular}{lccr}
\hline & Value & $\mathrm{df}$ & \multicolumn{2}{c}{ Asymp. Sig. (2-sided) } \\
\hline Pearson Chi-Square & $227.299^{\mathrm{a}}$ & 4 & .000 \\
\hline Likelihood Ratio & 242.837 & 4 & .000 \\
\hline $\begin{array}{l}\text { Linear-by-Linear } \\
\text { Association }\end{array}$ & 164.608 & $\mathrm{I}$ & .000 \\
\hline N of Valid Cases & & & \\
\hline
\end{tabular}

a. 2 cells $(5.5 \%)$ have expected count less than 5. The minimum expected count is 2.42 .

Table I0. Symmetric Measures (Food Quality and Organisational Growth)

\begin{tabular}{clcr}
\hline & & Value & Approx. Sig. \\
\hline Nominal by Nominal & Phi & .912 & .000 \\
\hline & Cramer's & .000 \\
& V & .645 & \\
\hline N of Valid Cases & & 273 & \\
\hline
\end{tabular}

The fourth chi-square table (Table 9) is determined between food quality and organisational growth. The Pearson Chi-square value is 227.299 with the sig value of 0.000 . Therefore, the relation between the variables is significant. Whereas the values of Phi in the symmetric measures (Table I0) is $0.9 \mathrm{I} 2$, so the relation is very strong.

Table II. Chi-Square Tests (Business Image and Organisational Growth)

\begin{tabular}{lccr}
\hline & Value & df & Asymp. Sig. (2-sided) \\
\hline Pearson Chi-Square & $429.353^{\text {a }}$ & 4 & .000 \\
\hline Likelihood Ratio & 323.513 & 4 & .000 \\
\hline $\begin{array}{l}\text { Linear-by-Linear } \\
\text { Association }\end{array}$ & 245.463 & $\mathrm{I}$ & .000 \\
\hline N of Valid Cases & 273 & & \\
\hline
\end{tabular}

a. 3 cells $(8.8 \%)$ have expected count less than 5 . The minimum expected count is $.5 \mathrm{I}$.

Table 12. Symmetric Measures (Business Image and Organisational Growth)

\begin{tabular}{clcr}
\hline & & Value & Approx. Sig. \\
\hline Nominal by Nominal & Phi & I.254 & .000 \\
\hline & Cramer's & .887 & .000 \\
V & & 273 & \\
\hline N of Valid Cases & & & \\
\hline
\end{tabular}

The fifth chi-square table (Table I I) is determined between brand image and organisational growth. The Pearson Chisquare value is 429.353 with the sig value of 0.000 . Therefore, the relation between the variables is significant. Whereas the values of Phi in the symmetric measures (Table I2) is I.254, so the relation is very strong.

Table I3. Chi-Square Tests (Service Quality and Organisational Growth)

\begin{tabular}{lccr}
\hline & Value & df & Asymp. Sig. (2-sided) \\
\hline Pearson Chi-Square & $217.759^{a}$ & 4 & .000 \\
\hline Likelihood Ratio & 221.119 & 4 & .000 \\
\hline $\begin{array}{l}\text { Linear-by-Linear } \\
\text { Association }\end{array}$ & I64.045 & I & .000 \\
\hline N of Valid Cases & 273 & & \\
\hline
\end{tabular}


a. 2 cells $(5.5 \%)$ have expected count less than 5 . The minimum expected count is I.69.

Table I4. Symmetric Measures Tests (Service Quality and Organisational Growth)

\begin{tabular}{clcr}
\hline & & Value & Approx. Sig. \\
\hline Nominal by Nominal & Phi & .893 & .000 \\
\hline & Cramer's & .632 & .000 \\
& V & & \\
\hline N of Valid Cases & & 273 & \\
\hline
\end{tabular}

The sixth chi-square table (Table I3) is determined between service quality and organisational growth. The Pearson Chi-square value is 217.759 with the sig value of 0.000 . Therefore, the relation between the variables is significant. Whereas the values of Phi in the symmetric measures (Table I4) is 0.893 , so the relation is very strong.

\subsection{Discussion}

The main aim of the research is associated with the identification of the significance of the factors that influence the organisational growth of companies in the hotel industry of Pakistan. The following explanation discusses the objectives that were developed in this study, in relation to the quantitative results that have been obtained through survey questionnaires. The results obtained from the survey questionnaires depict that there is a significant and strong association between the rate of customer retention and the organisational growth. The results that were obtained in this study are also validated with the results obtained in the study of Mohammed, Rashid and Tahir (2017) which depicts that if the organisation is able to retain their customers by adopting an effective retention strategy, then they are able to increase the growth of the organisation and are able to increase revenues for the business. The results obtained from the Spearman Correlation and Chi-Square test have avowed about the significant relationship between the satisfaction of customers and the organisational growth in the medium sized hotel industry of Pakistan. Furthermore, the results obtained after successful completion of descriptive analysis depict that organisations within the hotel industry need to ensure that they can satisfy the demands and requirements of the customer in order to improve their customer loyalty status, especially for Hotel Days Inn. Furthermore, the results obtained by the researcher can also be validated through the study of Leeman and Reynold (20I2), Bayraktar et al. (20I2), Kärnä (20I4) and Rauch et al. (2015). These authors have highlighted that if the organisations or businesses in the hotel industry are able to provide their customers with an extraordinary service and high quality with facilitate in increasing the satisfaction of customers which will further lead to the generation of higher profits and organisational growth.

Furthermore, successful completion of quantitative analysis allowed the researcher to measure the association between the price and the growth of the organisation. The factor of Price has been employed as the concept of relationship marketing, whereby Spearman Correlation and Chi-Square tests have specified a significant link between the two variables. Moreover, on the foundation of descriptive analysis that has been done, it has been noted by the researcher that customers can be also be satisfied if they perceive the pricing structure of Hotel Days Inn is lower as compared to the rest of the competitors in the market. As such, the researcher was able to validate these findings as per the study conducted by (Nicolau and Santa-María, 20I3; Lähteenmäki, 2013; Bowie et al., 2016; Abrate and Viglia, 2016; Weaver, 2014). Consequently, the research conducted by Kaura, Durga Prasad and Sharma (2015) further validate the findings of this study by depicting that the factor of price is important to ensure the satisfaction of the customers, whereby evidence can be provided in the case of Hotel Days Inn that the customers of the business were satisfied with prices offered by the business.

As such, after completing a critical review of the literature and analysing all the data that was obtained for this research, it has been noted by the researcher that customer retention and the satisfaction of the customers, are two of the main factors that improve or decrease the organisational growth of a company working within the hotel industry of Pakistan. Furthermore, from the findings that were obtained through analysis, it can evidently say that relationship marketing plays a major role in the medium hotel industry related to the growth of the organisation, sustainability and the survival of businesses operating under a fierce competition posed in the hotel industry.

\subsection{Hypothesis Summary}

\begin{tabular}{lll}
\hline S.No. & Hypothesis & $\begin{array}{c}\text { Accepted } \\
\text { /Rejected }\end{array}$ \\
\hline $\mathrm{Ha}:$ & $\begin{array}{l}\text { Customer retention of Pakistan's hotel industry affects the organisational growth } \\
\text { significantly. }\end{array}$ & Accepted. \\
\hline $\mathrm{Hb}:$ & Customer satisfaction of Pakistan's hotel industry affects the organisational growth Accepted. \\
\hline
\end{tabular}


significantly.

\begin{tabular}{lll}
\hline Hc: & Price of Pakistan's hotel industry affects the organisational growth significantly. & Accepted. \\
\hline Hd: & Food quality of Pakistan's hotel industry affects the organisational growth significantly. & Accepted. \\
\hline He: & Business image of Pakistan's hotel industry affects the organisational growth significantly. & Accepted. \\
\hline Hf: & Service quality of Pakistan's hotel industry affects the organisational growth significantly. & Accepted. \\
\hline
\end{tabular}

\section{Conclusion and Recommendation}

\section{I Conclusion}

The focal aim of this research was to investigate the elements of effective relationship marketing and the perceived effect on the overall growth of the organisation operating in the hotel industry of Pakistan. In this case, the business Hotel Days Inn has been selected in order to formulate the conclusion of this research. The overall findings of this research depict that the hotel industry in Pakistan is dynamic in nature and each organisation in this industry pose a fierce and high-level competition with each other. In addition, it has also been noted that if hotel companies are able to employ an effective customer retaining strategy, they are able to ensure and capitalise on the competitive edge in the market gained by them. As such, one the biggest asset to an organisation is their customer, and same is true for the hotel industry of Pakistan as organisations are able to generate revenues for their business through the customers. From this perspective, it is imperative that customer relationship marketing should be merged by employing the use of effective relationship marketing strategies and practice. The summary of the response obtained through the distribution of questionnaire is that many of the participants agree that customer retention aid an organisation in generating higher revenues for the business.

\subsection{Recommendations}

Following are some of the recommendations that can be employed in the future:

- Identification of target customers will allow businesses to have an effective relationship marketing with their customers.

- Informing customers will also businesses to attract large number of customers as the buying decision making process of the customer is influenced if they have been well informed of a hotel to the location, they are travelling

- An important factor in relationship marketing is the value of proposition, and hotel in Pakistan should ensure that they are able to incorporate this element in the services they provide to make sure that customers prefer their hotel over another competitor.

- Hotels in Pakistan industry should be able to provide safe and secure accommodation to their customers. This is due to the fact that in developing countries, such as Pakistan, it is important for customers to be aware that they are safe and secure in an unknown place.

\section{References}

Abrate, G., \& Viglia, G. (2016). Strategic and tactical price decisions in hotel revenue management. Tourism Management, 55, I23-I32.

Armelini, G., \& Villanueva, J. (20I I). Adding social media to the marketing mix. IESE insight, 9(9), 29-36.

Bayraktar, E., Tatoglu, E., Turkyilmaz, A., Delen, D., \& Zaim, S. (2012). Measuring the efficiency of customer satisfaction and loyalty for mobile phone brands with DEA. Expert Systems with Applications, 39 I), 99-106.

Bowie, D., Buttle, F., Brookes, M., \& Mariussen, A. (2016). Hospitality marketing. Taylor \& Francis.

Chaffey, D., \& Smith, P. R. (2017). Digital marketing excellence: planning, optimizing and integrating online marketing. Taylor $\&$ Francis.

Christopher, M., Payne, A., \& Ballantyne, D. (2013). Relationship marketing. Taylor \& Francis.

Coelho, P. S., \& Henseler, J. (2012). Creating customer loyalty through service customization. European Journal of Marketing.

Creswell, J. W. (2002). Educational research: Planning, conducting, and evaluating quantitative (pp. I46-166). Upper Saddle River, NJ: Prentice Hall.

Dabholkar, P. A. (2015). How to improve perceived service quality by increasing customer participation. In Proceedings of the 1990 academy of marketing science (AMS) annual conference (pp. 483-487). Springer, Cham.

Dar, M. S., Ahmed, S., \& Raziq, A. (2017). Small and medium-size enterprises in Pakistan: Definition and critical issues. Pakistan Business Review, I ( (I), 46-70.

Dominici, G., \& Guzzo, R. (2010). Customer satisfaction in the hotel industry: A case study from Sicily. International Journal of Marketing Studies, 2(2), 3-I2.

Grissemann, U.S., \& Stokburger-Sauer, N. E. (20120. Customer co-creation of travel services: The role of company support and customer satisfaction with the co-creation performance. Tourism Management, 33(6), I483-I492.

Grönroos, C. (2017). Relationship marketing readiness: theoretical background and measurement directions. Journal of Services Marketing, 3I(3), 218-225. 
Gummerus, J., von Koskull, C., \& Kowalkowski, C. (2017). Guest editorial: relationship marketing-past, present and future. Journal of Services Marketing, 3I(I), I-5.

Gummesson, E. (20II). Total relationship marketing. Routledge.

Gummesson, E. (2017). From relationship marketing to total relationship marketing and beyond. Journal of Services Marketing, 3I(I), I6-I9.

Hashim, I., Hashim, S., Yue bo, X., Ahmad, M., \& Mobin, M. (2016). Empirical Analysis of Pakistan Hotel industry based on SWOT Model. Journal of Tourism, Hospitality and Sports, I9(I), I7-24.

Hoteldaysinn.com.pk. (2019). Hotel Days Inn Karachil Pakistan / Page Array. Retrieved from https://www.hoteldaysinn.com.pk

Jones, G.R. (2010). Organisational theory, design, and change. Upper Saddle River: Pearson.

Kandampully, J., Zhang, T., \& Bilgihan, A. (20I5). Customer loyalty: a review and future directions with a special focus on the hospitality industry. International Journal of Contemporary Hospitality Management, 27(3), 379-4I4.

Kärnä, S. (20I4). Analysing customer satisfaction and quality in construction-the case of public and private customers. Nordic journal of surveying and real estate research, 2.

Kaura, V., Durga Prasad, C.S., \& Sharma, S. (2015). Service quality, service convenience, price and fairness, customer loyalty, and the mediating role of customer satisfaction. International Journal of Bank Marketing, 33(4), 404-422.

Kotler, P., Kartajaya, H., \& Setiawan, I. (2016). Marketing 4.0: Moving from traditional to digital. John Wiley \& Sons.

Lähteenmäki, L. (2013). Claiming health in food products. Food Quality and Preference, 27(2), 196-201.

Leeman, D., \& Reynolds, D. (2012). Trust and outsourcing: Do perceptions of trust influence the retention of outsourcing providers in the hospitality industry? International Journal of Hospitality Management, 3I(2), 60I-608.

Mohammed, A. A., Rashid, B. B., \& Tahir, S. B. (2017). Customer relationship management and hotel performance: the mediating influence of marketing capabilities_evidence from the Malaysian hotel industry. Information Technology and Tourism, $I 7(3), 335-361$.

Mok, C., Sparks, B., \& Kadampully, J. (2013). Service quality management in hospitality, tourism, and leisure. Routledge.

Nicolau, J.L., \& Santa-María, M.J., 2013. The effect of innovation on hotel market value. International Journal of Hospitality Management, 32, 7I-79.

Oly Ndubisi, N., \& Kok Wah, C. (2005). Factorial and discriminant analyses of the underpinnings of relationship marketing and customer satisfaction. International journal of bank marketing, 23(7), 542-557.

Palmatier, R. W. (2008). Relationship marketing. Cambridge, Mass, Marketing Science Institute.

Ramaseshan, B., Wirtz, J., \& Georgi, D. (2017). The enhanced loyalty drivers of customers acquired through referral reward programs. Journal of Service Management, 28(4), 687-706.

Rauch, D.A., Collins, M.D., Nale, R.D., \& Barr, P.B. (2015). Measuring service quality in mid-scale hotels. International Journal of Contemporary Hospitality Management, 27(1), 87-I06.

Raza, M.A., Siddiquei, A.N., Awan, H.M., \& Bukhari, K. (2012). Relationship between service quality, perceived value, satisfaction and revisit intention in hotel industry. Interdisciplinary journal of contemporary research in business, 4(8), $788-805$.

Sahin, A., Zehir, C., \& Kitapç1, H. (20II). The effects of brand experiences, trust and satisfaction on building brand loyalty; an empirical research on global brands. Procedia-Social and Behavioral Sciences, 24, I298.

Segoro, W. (2013). The influence of perceived service quality, mooring factor, and relationship quality on customer satisfaction and loyalty. Procedia-Social and Behavioral Sciences, 8I, 306-310.

Sheth, J. (2017). Revitalizing relationship marketing. Journal of Services Marketing, 3I(I), 6-I0.

Wang, X. L. (2012). Relationship or revenue: Potential management conflicts between customer relationship management and hotel revenue management. International Journal of Hospitality Management, 3I(3), 864-874.

Weaver, D. B. (20I4). Asymmetrical dialectics of sustainable tourism: Toward enlightened mass tourism. Journal of Travel Research, 53(2), I3I-I40.

Williams, A. (2006). Tourism and hospitality marketing: fantasy, feeling and fun. International Journal of Contemporary Hospitality Management, I8(6), 482-495.

Yen, C. H., Liu, L. L., Chen, C. Y., \& Lee, T. Y. (20I5). Customer relational benefits and relationship-marketing outcomes: comparing three transaction types of travel product. Asia Pacific Journal of Tourism Research, 20(2), I7I-I90.

Zhang, J.Z., Watson IV, G.F., Palmatier, R.W., \& Dant, R.P. (2016). Dynamic relationship marketing. Journal of Marketing, $80(5), 53-75$.

\section{Copyrights}

Copyright for this article is retained by the author(s), with first publication rights granted to the journal. This is an open-access article distributed under the terms and conditions of the Creative Commons Attribution license (http://creativecommons.org/licenses/by/4.0/). 